\title{
ОБ ОТЧЕТНОЙ СЕССИИ ИНСТИТУТА АРХЕОЛОГИИ ИМ. А.Х. МАРГУЛАНА
}

\author{
(C) 2019 г. Г.С. Джумабекова
}

Впервые после большого перерыва в Институте археологии им. А.Х. Маргулана в начале апреля 2019 г. была проведена отчетная сессия, на которой заслушаны доклады руководителей полевых исследований, проводившихся в полевом сезоне 2018 г. Спектр проведенных работ охватывает щирокие хронологические рамки от палеолита до Нового времени. Исследования проводились в рамках реализации задач по программно-целевому и грантовому финансированию Комитета науки Министерства образования и науки Республики Казахстан. Сотрудники экспедиций Института археологии им. А.Х. Маргулана вели работы на памятниках, расположенных на западе, северо-западе, центре, юге, юго-востоке Казахстана. Полевые исследования предполагали проведение раскопок и разведочно-поисковых мероприятий. В результате проведенных работ были получены новые данные по каменному и бронзовому векам, эпохе раннего железа, средневековья и Нового времени. В экспедициях Института археологии им. А.Х. Маргулана принимали участие специалисты из Нур-Султана, Актобе, Алматы, Жезказгана, Караганды, Костаная, Шымкента и др.

В резолюции, принятой по окончанию сессии, в качестве основного пункта прозвучало решение о необходимости вернуть традицию ежегодных отчетных сессий в г. Алматы в Институт археологии им. А.Х. Маргулана.

Ключевые слова: археология, Институт археологии им. А.Х. Маргулана, отчетная сессия, доклады, дискуссии

2-3 апреля 2019 г. в Институте археологии им. А.Х. Маргулана прошла отчетная сессия, посвященная итогам полевых исследований сотрудников в 2018 г. Археологи впервые после многолетнего перерыва вернулись к привычному формату заслушивания преимущественно отчетных докладов, ознакомивших присутствующих с результатами полевых исследований. Участниками отчетной сессии выступили держатели «Открытых листов» на право проведения полевых археологических работ.

Открыл отчетную сессию, выступив с приветственным словом, директор Института археологии им. А.Х. Маргулана Б.А. Байтанаев, который обозначил задачи собрания. Помимо необходимости непосредственно ознакомиться с полевыми исследованиями, проводимыми сотрудниками Института археологии им. А.Х. Маргулана, стояла задача обратить особое внимание на итоги работ молодых специалистов, оценить, при необходимости высказать замечания, скорректировать методику проведения полевых работ и т.п. В работе отчетной сессии приняли участие 21 человек, было заслушано 23 доклада.

Некоторые итоги изучения памятников эпохи камня были озвучены в докладах О.А. Артюховой и 


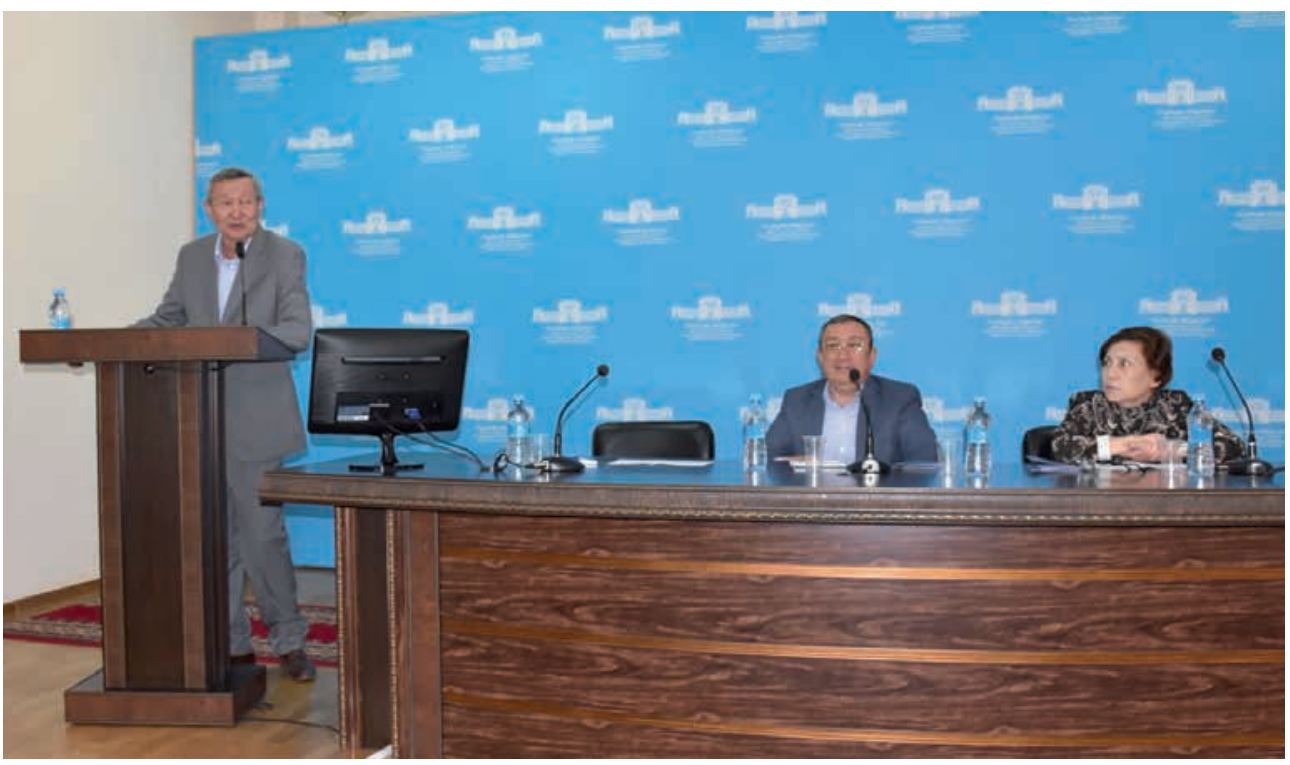

Выступление Ж. Курманкулова на открытии сессии. В президуме Б.А. Байтанаев, Г.С. Джумабекова. Фото Е.С. Казизова

Greeting by J. Kurmankulov at the opening of the session. In presidium B.A. Baitanayev, G.S. Jumabekova. Photo by E.S. Kazizov

Т.Б. Мамирова. В рамках изучения индустрии памятников эпохи камня проводилось исследование стратифицированной стоянки Улкен Жезды и многослойной голоценовой стоянки Токтаул в Центральном Казахстане. Памятник Улкен Жезды представляет стратифицированный объект эпохи позднего палеолита неолита-энеолита, в котором позднепалеолитические слои близки к памятникам Северного Прибалхашья, а голоценовый материал идентичен материалам неолитических культур Сарыарки. На стоянке Токтаул удалось проследить концентрации артефактов по слоям, выявить периоды мезолита, неолита, энеолита, этнографического времени.

В результате проведенных исследований была получена информация о времени заселения древними охотниками района, о характере каменной индустрии, о начале произ- водящего хозяйства в Центральном Казахстане.

Также О.А. Артюхова рассказала о некоторых итогах изучения палеолита Мангыстау. В 2018 г. проводились исследования по выявлению памятников каменного века в Западном Казахстане. В ходе работ на территории Актюбинской области обследовалось местонахождение Шаруа (Мартукский р-н), были намечены пути поиска следов палеолитического человека в месте находки мамонтовой фауны в бассейне реки Кобда. В ходе разведки обнаружены местонахождения и стоянки на берегах рек Терисаккан и Улкен Кобда, относящиеся к голоценовому времени.

В выступлении Т.Б. Мамирова кратко охарактеризованы результаты археологической разведки, проводившейся на территории Таскалинского района Западно-Казахстанской 
области и выявившей перспективные объекты, требующие дальнейшего более детального исследования.

Доклад «Итоги археологических исследований жилищамастерской на поселении Талдысай» А.С. Ермолаевой, прозвучавший первым, обрисовал роль Казахстанской горно-металлургической области в системе металлургических провинций Евразии, проблемы древней металлургии и металлообработки, возникающие при исследовании поселения Талдысай в Центральном Казахстане. В докладе были подведены некоторые итоги изучения одного из центров древней металлургии.

Тема изучения памятников эпохи бронзы была продолжена в докладе Д.А. Байтлеу на основе результатов разведки и исследования многослойного поселения Балкан в Центральном Казахстане.

C серией докладов выступил А.А. Горячев в соавторстве с Б.А. Байтанаевым, Д.А. Воякиным, А.А. Ергешбаевым, Т.А. Егоровой. В них отразились результаты систематизированного обследования ряда районов Алматинской и ЮжноКазахстанской областей - долины реки Усиктас, памятников эпохи палеометалла в верховьях ущелья Турген, пещеры Туттыбулак в долине Боролдая, горах Хантау.

В процессе исследования Хантауского транзитного коридора были проведены археологические разведки, позволившие собрать материал по топографии и планиграфии 115 памятников эпохи камня и палеометалла. Составлена предварительная карта памятников эпохи палеометалла Хантау. Особый интерес представляет южная часть Хантау, выбранная как ключевой район археологических исследований. Результатом исследо- ваний должно стать решение проблемы параметров влияния центральноказахстанского очага культурогенеза на развитие Жетысу в эпоху палеометалла (III-II тыс. до н.э.).

В процессе исследования пещеры Туттыбулак-1 были выявлены культурные слои от бронзового века до позднего средневековья. Авторами раскопа было высказано предположение о том, что в эпоху бронзы пещера служила временным пристанищем для охотников и собирателей, в эпоху ранних кочевников - для выплавки железа и крицы, активно пещера использовалась в раннем средневековье и в караханидский период вплоть до XVII в. Однако окончательный вывод о характере использования пещеры еще остается под вопросом. Данные исследований позволят изучать характер заселения долины р. Боролдай в древности.

Комплексные исследования проведены в верховьях р. Турген, позволившие, в частности, выполнить реконструкцию жилища поселения эпохи бронзы; составлена карта памятников долины реки Усиктас.

О результатах этноархеологических исследований, продолженных на участке р. Быжы в Алматинской области, изложено в выступлении И.К. Ахиярова. В результате выявлены и картографированы разновременные погребальные памятники от эпохи бронзы до Нового времени, а также многочисленные казахские зимовки. В результате их шурфовки в нижележащих слоях выявлены культурные слои эпохи поздней бронзы.

О результатах полевых исследований по теме гранта «Цивилизация номадов Тургая: от истоков к современности (по данным археологии и этноархеологии)» было изложено в сообщении Г.А. Базарбаевой. Работа 
состояла из двух направлений - разведки и раскопок. Разведки проводились в Амангельдинском и Джангильдинском районах Костанайской области. Основной упор был сделан на выявление объектов этноархеологического порядка. В результате проведения разведок отрядом под руководством Д.Б. Дуйсенбай были выявлены новые памятники, охватывающие временной отрезок от эпохи раннего железа до Нового времени, подготовлена карта памятников. Целью раскопок было проведение работ по доисследованию кургана 1 на могильнике Каратомар, обнаруженного экспедицией под руководством А.В. Логвина весной 2017 г. на левом берегу тобольского рукава Каратомарского водохранилища. В результате раскопок, проводившихся костанайскими археологами, были исследованы северная и западная части кургана, а также три погребения. Исследованные погребения на основании погребального обряда и типов сосудов отнесены к началу позднебронзового века.

Большой раздел отчетной сессии составили сообщения и доклады по изучению памятников городской средневековой культуры.

В докладе А.А. Нуржанова и А.С. Оразай «Археологические исследования городища Кастек» сообщалось, что в 2018 г. были исследованы два тюркско-карлукских слоя, датируемых второй половиной VII - первой половиной Х в. и три строительных горизонта, относящихся к Караханидскому периоду (вторая половина X - первая половина XIII в.). Городище Кастек - один из центров Караханидского государства, Западно-Тюркского и Карлукского каганатов, также он являлся средоточием городской культуры тюркских государств.
В докладе Б.А. Байтанаева и А.А. Ергешбаева сообщалось о ходе исследования сторожевых башен Испиджаба. В результате проведенных работ были выявлены принципы устройства башен, их конструктивные особенности, строительные приемы, закономерности локализации, их назначение.

Об исследованиях каравансарая Шенгельды (Алматинская обл.) изложено в докладе Д.А. Талеева. В отчетный период изучалась северозападная часть караван-сарая. Были выявлены крепостные стены и ворота караван-сарая. С внутренней стороны крепостной стены было выявлено помещение с небольшой печью. По керамическому материалу, полученному из раскопок крепостной стены, караван-сарай Шенгелды датируется $\mathrm{X}$ - серединой XIII в.

В 2018 г. были продолжены исследования городища Талгар, сосредоточенные на восточном квартале, изучались параметры и структура восточной крепостной стены. Установлено, что тулово стены формировалось из чередующихся 22 ленточных слоев. Керамический материал, полученый в ходе раскопок разреза крепостной стены городища Талгар, позволяет датировать данный участок второй половиной XIII - началом XIV в. (Камалдинов И.Р.)

На городище Илибалык, расположенном в Илейской долине, в юговосточной части Алматинской области, были проведены комплексные научно-исследовательские работы, включающие в себя археологические исследования, геодезическую съемку, аэрофтосъемку, геомагнитное сканирование, документирование результатов археологических работ. Уточнены топографическая структура и гидрогеология городища Илибалык, проведена обработка и анализ данных геомагнитного сканирова- 


\section{ҚАЗАҚСТАН АРХЕОЛОГИЯСЫ № 2 (4) 2019}

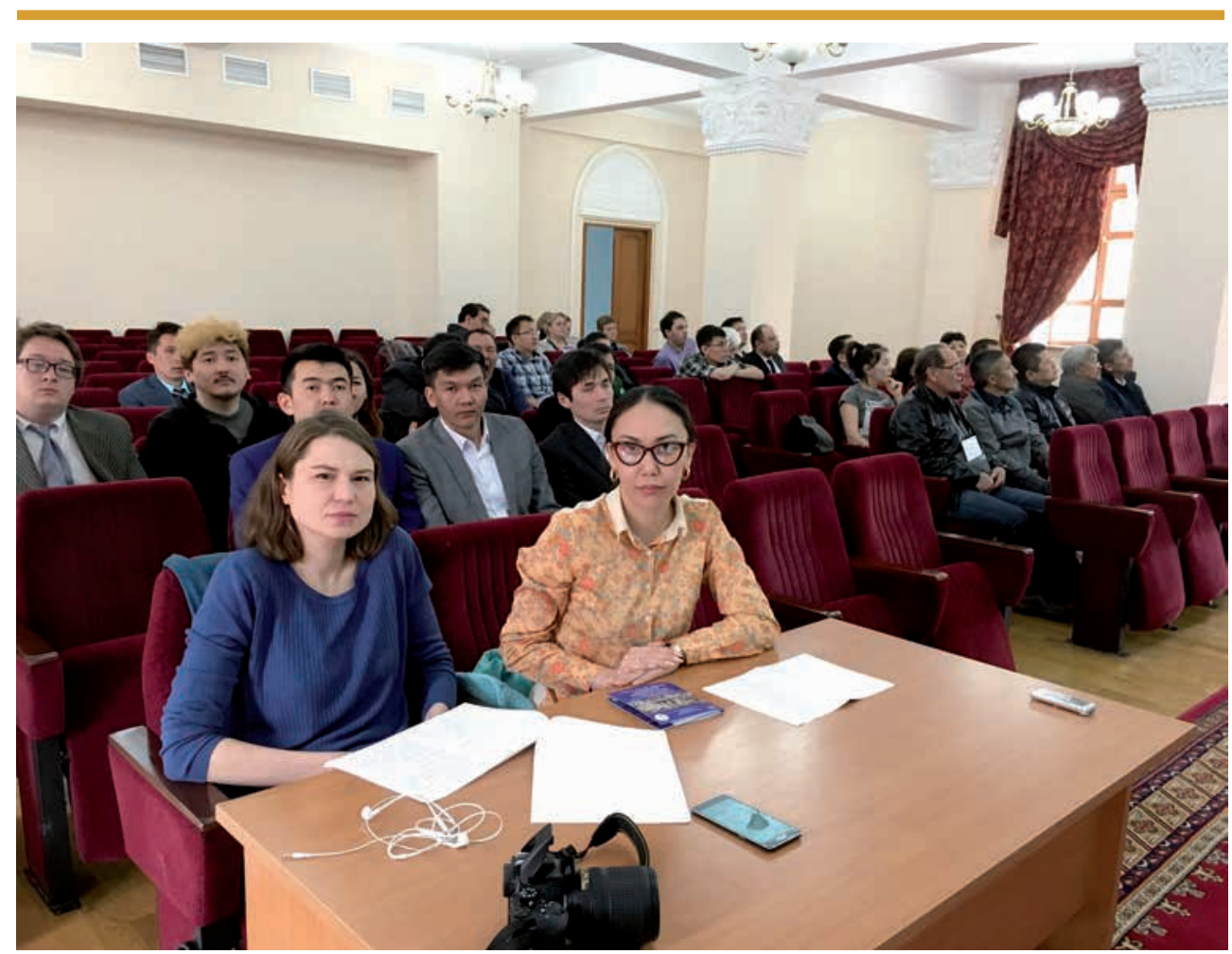

Участники отчетной сессии. На переднем плане секретари заседания: Е.В. Дубягина и А.Д. Касенова. Фото Е.С. Казизова

Participants of the session. At the forefront are the secretaries of the meeting of E. Dubyagina and A. Kasenova. Photo by E.S. Kazizov

ния территории некрополя городища Илибалык, проведена всесторонняя фотофиксация и аэровидеосъемка, построен ортофотоплан, позволяющий задокументировать памятник без оптических искажений (Сорокин Д.).

В докладе Е.Ш. Акымбек «Исследование средневековых торткулей в долине Шу» подведены итоги исследований, включающих поисковоразведочные работы, закладку шурфов и траншей на торткулях. Изучены объекты Шыгыс Жинишке, Кенес, Коскудык. Выявлены функции, параметры, строительные материалы и приемы на внешних оборонительных стенах торткулей Ыстобе, Какпатас, Танабай, получены данные о торткулях Актобе, Бирлик, Торткуль (Ынталы), Кумозек, Жазык и средневекового города Актобе в долине
Шу. Всего на территории городища и окрестностей были исследованы 11 торткулей.

М.С. Шагирбаев доложил об исследованиях средневековых памятников в долине реки Курты. В ходе исследовательских работ были зафиксированы местоположения средневековых торткулей Енбекши, Итбай, Кокозек, Самсы, Актерек, Аркарлы, Жайсан. В результате проведенных исследований выявлены их современное состояние, планировка, охарактеризована оборонительная система в долине Курты.

В полевой сезон 2018 г. проводились исследования на археологическом разновременном комплексе Самсы (Жамбылский р-н, Алматинская обл.). Большая часть погребальных сооружений, возможно, датиру- 
ется средневековым периодом и относится к городищу Самсы, расположенному в 500 м западнее. Основной целью исследований на комплексе Самсы являлось проведение рекогносцировочных работ для получения информации о памятнике. Исследованные объекты датируются эпохой бронзы и ранних кочевников (Казизов Е.C.).

Необходимость и важность применения методов естественных наук в археологических исследованиях прозвучали в докладе С.А. Нигматовой. Были представлены результаты карпологических исследований захоронения из кургана Урджар и палинологических исследований материалов памятников долины р. Турген. Полученные результаты значительно усиливают достоверность и объективность предположений, расширяют базу данных для научных реконструкций как в материальной, так и в духовной сфере жизни древних коллективов.

По итогам отчетной сессии к.и.н., директором филиала Института археологии им. А.Х. Маргулана МОН РК Т.Б. Мамировым были внесены следующие предложения, получившие одобрение остальных участников:

1. Проводить ежегодные Маргулановские чтения на базе Института археологии имени А.Х. Маргулана. Это позволит проводить отчетные сессии и заслушивать результаты полевых работ, проводимых археологами различных научных центров в Казахстане в рамках отчетной сессии в Институте археологии.
2. Поднять вопрос о создании Полевого комитета на базе Института археологии имени А.Х. Маргулана, либо Комитета науки МОН РК, с наделением функций рекомендаций на получение Лицензий на осуществление археологических работ и проведения контроля за качеством и своевременной сдачей полевых отчетов в архив Института археологии имени А.Х. Маргулана.

3. Разработать единый «Полевой дневник археолога» для сотрудников Института археологии имени A.X. Маргулана и специалистов научных центров Республики Казахстан с указанием необходимых пояснений при проведении археологических работ и законодательных документов по охране и изучению памятников историко-культурного наследия.

4. Сформулировать и выдвинуть предложение по увеличению срока обработки археологического материала, в том числе для проведения анализов, полученного в ходе полевых работ, до передачи в ведомство Комитета культуры РК (музеи) сроком до трех лет, вместо принятого одного года.

5. Внедрить обязательную практику рецензирования статей молодых сотрудников Института археологии имени А.Х. Маргулана руководителями отделов для повышения качества публикуемых работ.

В целом стоит отметить интересное содержание и высокий уровень докладов, отражающий широкий спектр проводимых сотрудниками Института археологии им. А.Х. Маргулана археологических исследований на территории Казахстана.

\section{Сведения об авторе:}

Джумабекова Гульнара Саиновна - кандидат исторических наук, ведущий научный сотрудник, Институт археологии им. А.Х. Маргулана (г. Алматы, Казахстан); gdzhuma@mail.ru 


\title{
Ә.Х. МАРҒҰЛАН АТЫНДАҒЫ АРХЕОЛОГИЯ ИНСТИТУТЫНЫН ЕСЕПТІК СЕССИЯСЫ ЖАЙЫНДА
}

\author{
г.С. Жұмабекова
}

2019 жылдың сәуір айының басында Ә.Х. Марғұлан атындағы Археология институтының көп жылдарғы үзілістен кейін бірінеші рет есептік сессия өткізілді, мұнда 2018 жылғы далалық маусымда жүргізілген далалық зерттеу жетекшілерінің баяндамалары тыңдалды. Жүргізілген жұмыстардың ауқымы палеолиттен бастап Жаңа кезеңге дейінгі хронологиялық кең шеңберді қамтиды. Зерттеулер Қазақстан Республикасының Білім және ғылым министрлігі Ғылым комитетінің мақсатты бағдарлама мен гранттық қаржыландыру бойынша алдыға қойылған мақсатарды іске асыру шеңберінде жүргізілді. Ә.Х. Мағұлан атындағы Археология институты экспедициясының қызметкерлері Қазақстанның батысында, солтүстік-батысында, орталығында, оңтүстігінде, оңтүстік-шығысында орналасқан ескерткіштерде жұмыстар жүргізді. Далалық зерттеулер далалық және барлау-іздеу іс шараларын жоспарлады. Жүргізілген жұмыстар нәтижесінде тас және қола дәуірі, ерте темір ғасыры, ортағасырлар мен Жаңа кезең бойынша жаңа мәліметтер алынды. Ә.Х. Марғұлан атындағы Археология институтының экспедиияларына Нұр-Сұлтан, Ақтөбе, Алматы, Жезқазған, Қарағанды, Қостанай, Шымкент және басқа да қалалардың мамандары қатысты.

Сессияның соңында қабылданған қарардың негізгі пункті Ә.Х. Марғұлан атындағы Археология институтында Алматы қаласында жыл сайынғы есептік сессияны өткізу дәстүрін жалғастыру шешімі болды.

Түйін сөздер: археология, Ә.Х. Марғұлан атындағы Археология институты, есептік сессия, баяндамалар, пікір алмасу

\section{ON THE REPORTING SESSION OF A.KH. MARGULAN INSTITUTE OF ARCHAEOLOGY}

\section{G.S. Jumabekova}

For the first time after a long break A.Kh. Margulan Institute of Archaeology in the beginning of April 2019 held a reporting session. Reports of managers of field studies carried out in the field season 2018 were heard at the session. The spectrum of works carried out covers a wide chronological framework - from the Paleolithic to the New Age. The studies were carried out within the framework of implementing the tasks of the program-targeted and grant financing of the Committee of Science of the Ministry of Education and Science of the Republic of Kazakhstan. The staff of the expeditions of A.Kh. Margulan Institute of Archaeology carried out works on monuments located in the west, north-west, centre, south, south-east of Kazakhstan. The field studies included excavations and exploration-search activities. As a result of these works, new data were obtained on the Stone and Bronze ages, the era of Early iron, the Middle Ages and the New Age. The expeditions of A.Kh. Margulan Institute of Archaeology were attended by experts from Nur-Sultan, Aktobe, Almaty, Jezkazgan, Karagandy, Kostanay, Shymkent, etc.

In the resolution adopted at the end of the session, the decision about the need to return the tradition of the annual reporting sessions to Almaty to A.Kh. Margulan Institute of Archaeology was sounded as the main point.

Keywords: archaeology, A.Kh. Margulan Institute of Archaeology, reporting session, reports, discussions

About the Author:

Jumabekova Gulnara S. Candidate of Historical Sciences, Leading Researcher, A.Kh. Margulan Archeology Institute, Almaty, Kazakhstan, gdzhuma@mail.ru 